\title{
Sex Chromatin and Chromosome Abnormalities among 10,412 Liveborn Babies
}

\author{
S. N. PANTELAKIS, OLIA-MARIA CHRYSSOSTOMIDOU, D. ALEXIOU, \\ T. VALAES, and S. A. DOXIADIS \\ From the Institute of Child Health, Athens, and The Neonatal Unit of the State and University \\ 'Alexandra' Maternity Hospital, Athens, Greece
}

\begin{abstract}
Pantelakis, S. N., Chryssostomidou, Olia-Maria, Alexiou, D., Valaes, T., and Doxiadis, S. A. (1970). Archives of Disease in Childhood, 45, 87. Sex chromatin and chromosome abnormalities among 10,412 liveborn babies. Among 10,412 liveborn infants surveyed in a large maternity hospital in a 2-year period, there were 13 cases $(0 \cdot 13 \%)$ of discrepancy between sex phenotype and sex chromatin $(0.15 \%$ among male infants and $0.10 \%$ among female infants). There were 22 cases of trisomy-21 (incidence $0.21 \%$ ), 3 cases of trisomy-18, and 1 case of trisomy-13-15. 9 cases presented multiple congenital abnormalities but the karyotype was normal.

Only the incidence of cases with Down's syndrome is higher than that reported in the literature. Maternal and paternal age, seasonal clustering, infectious diseases before or at the beginning of pregnancy, and $x$-ray exposure of parents, showed no correlation with Down's syndrome. Among the cases of Down's syndrome there was a significantly higher maternal and paternal mean age and a maternal history of infectious hepatitis was more frequent.
\end{abstract}

Since Moore and Barr (1955) described the method of determining the sex chromatin by examining the nuclei of the cells of the oral mucosa, it has been possible to screen large populations for sex chromosome abnormalities. During the past few years several authors have undertaken such sex chromatin surveys on newborn populations in order to establish the frequency of discrepancies between sex genotype and sex phenotype.

A range of discrepancy, perhaps related to differences of the ethnic groups studied, has been found from $0 \%$ in India (Naik and Shah, 1962) to $0.23 \%$ in Scotland (Maclean et al., 1964) and Mexico (Márquez-Monter, Carnevale-López, and Kofman-Alfaro, 1968). Some authors (Robinson and Puck, 1965) have suggested that sex chromosome abnormalities due to non-disjunction are perhaps related to external factors. More studies are needed in order: (1) to elucidate the problem of the over-all frequency, (2) to look for any differences in the incidence between the two sexes, (3) to investigate the relation of the frequency in the ethnic group studied to external factors such as

Received 18 July 1969. epidemics of viral infections, use of drugs, or exposure to $x$-rays.

The present study concerns a neonatal survey of all liveborn babies born at the State and University Maternity Hospital 'Alexandra' during a two-year period (1.10.66-30.9.68). The current practice in Greece, and particularly in the area of Athens, is for unselected hospital delivery, and this is the case for over $90 \%$ of the deliveries.

\section{Material and Methods}

During the period of study each pregnant woman admitted for delivery was included in the survey. Details about her social class, age, previous medical history, and medical history of her husband were collected, on a questionary of about 80 coded questions. For each newborn child sex chromatin determination was performed blindly on the amnion membranes according to the method of Klinger (1957) as modified by J. H. Edwards (personal communication, 1964). The results were afterwards compared with the sex phenotype. All newborns were clinically examined by one of us. In cases of discrepancy or low Barr bodies count, buccal smears were examined for confirmation of the findings by the method of Moore and Barr (1955) with minor modifications. For all newborn infants 
who either presented a discrepancy between sex chromatin and sex phenotype, or were found to have multiple congenital abnormalities or anomalies suggesting one of the known trisomic syndromes, a full clinical examination was done and karyotyping was performed by white blood cell culture according to the method of Moorhead et al. (1960) as modified by de Grouchy, Roubin, and Passage (1964).

\section{Results}

The method we have used for the evaluation of sex chromatin from amnion membranes gave satisfactory and reliable results (Pantelakis and Panagopoulos, 1968). Among 500 female newborns the mean percentage of nuclei with presence of Barr bodies was $42 \cdot 5 \%$ (SD $10 \cdot 4 \%$ ) (Fig.).

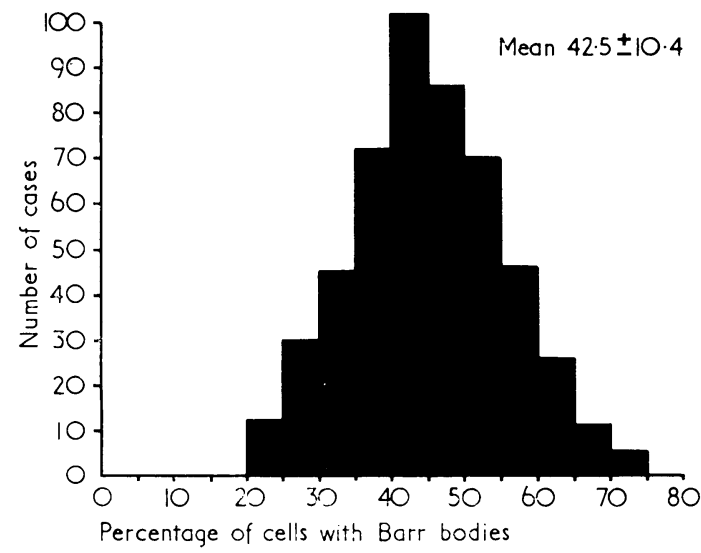

FIg.-Percentage distribution of Barr body positive nuclei in amniotic membrane preparations from 500 female newborns.

Among the male infants scores were never above $2^{\circ}{ }_{0}$. All cases with a score below $2 \mathrm{SD}$ from the mean were considered as suspects for mosaicism, and the karyotype was examined.

During the two-year period of the investigation 13,823 women were admitted for delivery. The liveborn babies in whom sex chromatin was examined were 10,412 and they were not selected (Table I). In the material studied the rate of

TABLE I

Analysis of Material

\begin{tabular}{|c|c|c|c|c|c|}
\hline \multicolumn{5}{|c|}{ Women delivered during period of survey } & \multirow{2}{*}{$\begin{array}{l}13,823 \\
3.2 \%\end{array}$} \\
\hline Stillbirths $\ldots$ & . & . & . & . & \\
\hline Multiple births & . & . & & . & $1 \cdot 2{ }^{\prime \prime}$ \\
\hline Primiparae .. & . & . & . & . & $38^{\prime \prime}$ \\
\hline Multiparae . . & . & . & . & . & $62 " 0$ \\
\hline \multicolumn{5}{|c|}{ Liveborn babies with sex chromatin deter- } & \\
\hline mination & . & . & . & . & $\begin{array}{l}10,412 \\
\left(78^{\circ}{ }_{0}\right)\end{array}$ \\
\hline
\end{tabular}

stillbirths was $3.2 \%$ and that of multiple birthy $1.2 \%$. $38 \%$ of the mothers were pimiparae an $62 \%$ were multiparae. These frequencies we found to be essentially the same when considerin either the total number of women admitted or the number of women whose babies had their sex chromatin examined.

The over-all incidence of discrepancy betwee sex phenotype and sex chromatin as well as the incidence separately in male and female newboros is shown in Table II. As can be seen in thij

TABLE II

Incidence of Sex Chromatin Abnormalities Among 10,412 Liveborn Babies

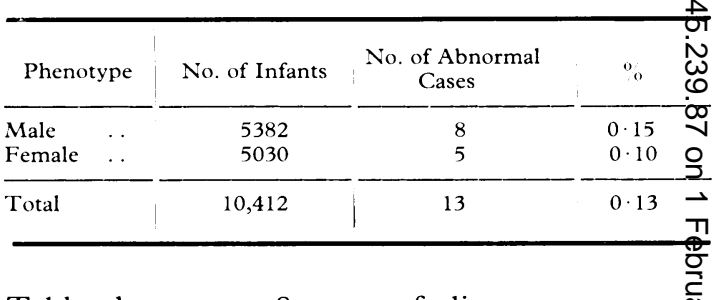

Table there were 8 cases of discrepancy amom the 5382 phenotypical male newborns screened (an incidence of $0 \cdot 15^{\circ}$ ) and 5 cases among the 5030 phenotypical females (an incidence of $0 \cdot 1$ (\$).

In Table III are given the details of the chro somal constitution of the 13 cases which have

TABLE III

Chromosomal Constitution of 13 Cases of Sex Chromatin Discrepancy

\begin{tabular}{|c|c|c|}
\hline Syndromes & No. of Cases & Incidence "." \\
\hline Klinefelter XXY & 6 & $0 \cdot 11$ \\
\hline Mosaics XXY/XY & 2 & $0 \cdot 04$ \\
\hline Turner XO & - & - \\
\hline Mosaics XO XX & 2 & $0 \cdot 04$ \\
\hline Superfemale XXX & 3 & $0 \cdot 06$ \\
\hline Total & 13 & $0 \cdot 13$ \\
\hline
\end{tabular}

considered as abnormal on sex chromatin screenimg because they were found to present: (a) a discre ancy between phenotype and sex chromatin, for (b) a Barr body count less than 2 SD from the mean for our method (mean $42.5 \% \div 10.4 \%$ ), 伯 (c) two or more chromatin masses. Thus, amoag the male newborns there were 6 cases of XXY Klinefelter's syndrome and 2 cases of XXY/XYY mosaics. Among the female newborns there we 2 cases of $\mathrm{XO} / \mathrm{XX}$ mosaics and 3 cases of XXX.?

In Table IV are presented the social class and 
TABLE IV

Social Class and Maternal and Paternal Age of Cases with Sex Chromatin Abnormalities

\begin{tabular}{|c|c|c|c|c|c|c|}
\hline \multirow{2}{*}{ Social Class } & \multirow{2}{*}{$\begin{array}{l}\text { Total No. } \\
\text { Examined }\end{array}$} & \multirow{2}{*}{ Abnormal Cases } & \multicolumn{2}{|c|}{ Mean Maternal Age (yr.) } & \multicolumn{2}{|c|}{ Mean Paternal Age (yr.) } \\
\hline & & & Normal & Abnormal & Normal & Abnormal \\
\hline $\begin{array}{l}1 \\
2 \\
3\end{array}$ & $\begin{array}{r}396 \\
1,353 \\
8,663\end{array}$ & $\frac{-}{13}$ & $\begin{array}{ll}28 & 8 / 12 \\
28 & 2 / 12 \\
27 & 5 / 12\end{array}$ & $29-\frac{}{8 / 12}$ & $32 \begin{array}{l}36 \\
34 \\
3 / 12\end{array}$ & $35 \overline{2 / 12}$ \\
\hline Total & 10,412 & 13 & $276 / 12$ & $298 / 12$ & $327 / 12$ & $35 \quad 2 / 12$ \\
\hline
\end{tabular}

the maternal and paternal mean ages of the whole material in comparison to those of the 13 cases with sex chromosome abnormalities. For practical reasons it was decided to distinguish the women studied in three main social classes according to education, occupation, and standard of living. As can be seen from this Table the great majority of these women ( $83 \%$ ) belong to the lower social class. The mean maternal and paternal age of the abnormal cases was a little higher than that of the total but not significantly so.

In Table $\mathrm{V}$ is shown the incidence of phenotypically abnormal babies with autosomal trisomies. There were 22 cases of trisomy-21,

\section{TABLE V}

Incidence of Autosomal Trisomies and Multiple Congenital Abnormalities among 10,412 Liveborn Newborns

\begin{tabular}{|c|c|c|}
\hline Syndrome & No. of Cases & Incidence $(\%)$ \\
\hline $\begin{array}{l}\text { Trisomy-21 .. } \\
\text { Trisomy-18 .. } \\
\text { Trisomy-13-15 .. } \\
\text { Multiple congenital } \\
\text { abnormalities } \\
\text { with normal } \\
\text { karyotype }\end{array}$ & $\begin{array}{r}22 \\
3 \\
1\end{array}$ & $\begin{array}{l}0 \cdot 21 \\
0 \cdot 03 \\
0 \cdot 01\end{array}$ \\
\hline
\end{tabular}

3 cases of trisomy-18, and 1 case of trisomy13-15. 9 cases with multiple congenital abnormalities were found to have normal karyotypes.

In Table VI are presented the social class and the maternal and paternal mean age of these cases. 18 cases of Down's syndrome were born to women belonging to the 3 rd social class, while 4 infants were born to women belonging to the 1st and 2nd social class. The mean maternal and paternal ages of the newborns with Down's syndrome were significantly higher than the maternal and paternal mean ages of the normal newborns.

The analysis of factors such as infectious diseases or $x$-ray exposure immediately before or at the beginning of pregnancy showed no relation between these factors and the occurrence of sex chromatin discrepancy or Down's syndrome.

A history of maternal infectious hepatitis (as diagnosed at the time of the disease by the attending doctor) before the present pregnancy was more frequent among the mothers of babies with Down's syndrome. As cases with Down's syndrome were born to mothers of an older age and the chances of having had infectious hepatitis were higher, we present in Table VII a more detailed analysis of the incidence of infectious hepatitis in our material in different age-groups. As it is shown in this Table the incidence of infectious hepatitis in the maternal history increases from $3 \cdot 35 \%$ among

TABLE VI

Social Class and Maternal and Paternal Age in Cases with Down's Syndrome

\begin{tabular}{|c|c|c|c|c|c|c|c|c|}
\hline \multirow[t]{2}{*}{ Social Class } & \multirow{2}{*}{$\begin{array}{c}\text { Total } \\
\text { Examined } \\
\text { and Percentage }\end{array}$} & \multirow[t]{2}{*}{$\begin{array}{l}\text { Down's } \\
\text { Syndrome }\end{array}$} & \multirow{2}{*}{$\begin{array}{c}\text { Other } \\
\text { Trisomies }\end{array}$} & \multirow{2}{*}{$\begin{array}{c}\text { Multiple } \\
\text { Congenital } \\
\text { Abnormalities }\end{array}$} & \multicolumn{2}{|c|}{$\begin{array}{l}\text { Maternal Age (yr.) } \\
\text { (mean and range) }\end{array}$} & \multicolumn{2}{|c|}{$\begin{array}{l}\text { Paternal Age (yr.) } \\
\text { (mean and range) }\end{array}$} \\
\hline & & & & & Normals & Down's & Normals & Down's \\
\hline $1 \mathrm{st}$ & $396(3 \cdot 8 \%)$ & 2 & - & 1 & $\begin{array}{c}28 \quad 8 / 12 \\
(17-44)\end{array}$ & 29,31 & $\begin{array}{c}36 \\
(23-60)\end{array}$ & 39,41 \\
\hline 2nd & $1353(12 \cdot 9 \%)$ & 2 & - & - & $\begin{array}{c}282 / 12 \\
(16-41)\end{array}$ & 27,35 & $\begin{array}{c}34 \\
(18-65)\end{array}$ & 32,42 \\
\hline 3 rd & $8663(83 \cdot 3 \%)$ & 18 & 4 & 8 & $\begin{array}{c}275 / 12 \\
(14-50)\end{array}$ & $\begin{array}{c}35 \\
(24-50)\end{array}$ & $\begin{array}{c}323 / 12 \\
(17-68)\end{array}$ & $\begin{array}{c}38 \\
(28-60)\end{array}$ \\
\hline Total & 10,412 & 22 & 4 & 9 & $276 / 12$ & $34 \quad 1 / 12$ & $327 / 12$ & $1 / 12$ \\
\hline
\end{tabular}


TABLE VII

History of Infectious Hepatitis in Mothers of Different Age-groups

\begin{tabular}{c|c|c|c}
\hline $\begin{array}{c}\text { Age-group } \\
\text { (yr.) }\end{array}$ & $\begin{array}{c}\text { No. of } \\
\text { Cases }\end{array}$ & $\begin{array}{c}\text { No. with Positive } \\
\text { History of Infectious } \\
\text { Hepatitis }\end{array}$ & Incidence (\%) \\
\hline-24 & 3455 & 116 & $3 \cdot 35$ \\
$25-29$ & 3075 & 122 & 3.96 \\
$30-34$ & 2500 & 146 & $5 \cdot 84$ \\
35 and over & 1248 & 77 & $6 \cdot 17$ \\
\hline Total & 10,278 & 461 & $4 \cdot 48$ \\
\hline
\end{tabular}

women up to 24 years old to $6 \cdot 17 \%$ among women aged 35 years and more.

In Table VIII the incidence of a history of infectious hepatitis among mothers over 30 years with normal babies is compared with that of mothers who gave birth to infants with Down's syndrome. As it appears from this Table a history of maternal infectious hepatitis was commoner in the group with Down's syndrome. The numbers of the cases with this condition are small for definite conclusions; statistical analysis, however, showed the difference between the incidence in the two groups to be significant $\left(\chi^{2}=6.45\right.$ and $\left.p<0.025\right)$.

\section{TABLE VIII}

Incidence of Infectious Hepatitis in Maternal History of Newborns with Down's Syndrome and of Normal

Newborns Born to Mothers Older than 30 years

\begin{tabular}{l|c|c|c}
\hline & \multicolumn{2}{|c|}{ History of $\begin{array}{c}\text { Maternal Infectious } \\
\text { Hepatitis }\end{array}$} \\
\cline { 2 - 4 } & Absent & Present & Total \\
\hline $\begin{array}{l}\text { Normal newborns } \\
\text { Newborns with Down's } \\
\text { syndrome } \ldots\end{array}$ & 3748 & $223(5.9 \%)$ & 3.971 \\
\hline Total & 18 & $4(18 \%)$ & 22 \\
\hline
\end{tabular}

$x^{2}=6.45 ; p<0.025$

\section{Discussion}

In surveys where nuclear sexing is used as screening method for the detection of sex chromosome anomalies those affecting the $\mathrm{Y}$ chromosome will not be detected. Thus a case of XYY will not present a discrepancy between sex chromatin and sex phenotype. The frequency of this abnormality is assumed to be $1: 1000$ in the liveborn male population (Court Brown, 1968).

The material usually examined for sex chromatin determination is buccal mucosa. This examina- tion, however, can be performed in all other tissues. During the first 2 days of life it is know that the percentage of nuclei with presence $\overline{\text { of }}$ Barr bodies in buccal smears in female newbor can be below $20 \%$ (Smith et al., 1962; Taylơ, 1963; Frasier, Crudo, and Farrell, 1964). On the other hand, the collection of buccal smears from all newborns during the first $\mathbf{4 8}$ hours after bir presents technical difficulties.

We believe that the advantages of studying the sex chromatin on amnion membranes in the neonatal period can be summarized as followis: (a) the collection of placenta in the delivery room is simple, does not require specialized personnest, and does not disturb the neonate; (b) the examing tion can be performed in stillbirths or neonates dying a few hours after delivery; (c) the score of nuclei with Barr bodies present among the femat newborns is high enough to make readings easg and to indicate suspects for mosaicism; (d) it is easy to examine as many specimens from the amnion membranes as are needed to obtain a satisfactorip preparation.

The frequency of sex chromatin discrepancies the newborn population in different countries reported in the literature is presented in Table IX.

TABLE IX

Incidence of Sex Chromatin Anomalies in Newboras as Reported in Various Parts of World and in Presemt

\begin{tabular}{|c|c|c|c|}
\hline Authors & Country & $\begin{array}{l}\text { Total No. } \\
\text { of Subjects }\end{array}$ & $\begin{array}{c}\text { Abnormaliti } \\
(\%)\end{array}$ \\
\hline $\begin{array}{l}\text { Naik and Shah } \\
\text { (1962) } \\
\text { Wiesli (1962) .. } \\
\text { Moore (1959) .. } \\
\text { Bergemann (1961) } \\
\text { Maclean, Harnden, } \\
\text { and Court } \\
\text { Brown (1961) } \\
\text { Maclean et al. } \\
\text { (1964) .. } \\
\text { Robinson and } \\
\text { Puck (1967) } \\
\text { Taylor and } \\
\text { Moores (1967) } \\
\text { Márquez-Monter } \\
\text { et al. (1968) }\end{array}$ & $\begin{array}{l}\text { India } \\
\text { Switzerland } \\
\text { Canada } \\
\text { Switzerland } \\
\text { Scotland } \\
\text { Scotland } \\
\text { United States } \\
\text { England } \\
\text { Mexico }\end{array}$ & $\begin{array}{r}6000 \\
14,725 \\
6900 \\
9688 \\
3000\end{array}$ & $\begin{array}{l}0.23 \\
0 \cdot 16 \\
0.17 \\
0 \cdot 20 \\
0.23\end{array}$ \\
\hline Present study .. & Greece & 10,412 & $0 \cdot 13$ \\
\hline
\end{tabular}

With the exception of the studies in India (Naik and Shah, 1962) and in Switzerland (Wiesli, 1962) where very low figures have been reported, the findings of the other investigators vary between $0.13 \%$ and $0.23 \%$.

In fact, if one takes into consideration only the 
surveys with more than 6000 cases, the variation is even smaller. The similarity of the findings shows that probably there are no important variations related to ethnic or geographic differences. The findings in India by Naik and Shah (1962) require confirmation.

During the two years of our investigation we found 13 cases of sex chromosome abnormalities. All of them were clinically normal and they would never have been detected at this early age if sex chromatin examination was not performed. Among the 13 there was not a single case of Turner's syndrome. The low incidence of Turner's syndrome among liveborn babies agrees with the published reports (Moore, 1959; Maclean et al., 1964), and is in contrast with the other anomalies of the $\mathrm{X}$ chromosome in females, such as mosaics $\mathrm{XO} / \mathrm{XX}$ and $\mathrm{XXX}$ females. This fact may mean that the embryo with $\mathrm{XO}$ constitution is more vulnerable and more apt to end in an abortion. Studies on material of abortions and stillbirths have indeed shown a much higher incidence of XO aberrations (Carr, 1965; Maclean et al., 1964; Szulman, 1965).

Kohn, Winter, and Mellman (1968) reviewing the literature on trisomy-X mention that only 12 newborn infants with an XXX constitution have been reported. This can perhaps be explained by the absence of characteristic phenotype in the newborn period. Diagnosis of isolated trisomy-X in the newborn period can only be made during neonatal surveys with routine sex chromatin examination. The present study adds three more asymptomatic cases; it will be extremely interesting to watch the future development of these children as well as those with Klinefelter's syndrome (XXY) and with mosaicism.

Robinson and Puck (1967) tentatively concluded that the incidence of sex chromosome abnormalities was related to the socio-economic group studied and moreover presented a seasonal clustering. They did not find the same factors to play any role in the occurrence of Down's syndrome. Frøland (1967), analysing the dates of birth of 80 patients with sex chromosome abnormalities, found a distribution not significantly different from that expected. The 13 cases with sex chromosome anomalies of the present study did not show any clear-cut seasonal clustering.

The present study does not help to elucidate the relation between socio-economic condition and incidence of sex chromosome abnormalities. $83 \%$ of the material studied belonged to the lower social class, and no comparison with a higher social class was therefore possible.
The analysis of other factors such as maternal and paternal age, infectious diseases immediately before or during pregnancy, and $x$-ray exposure did not show any correlation with the occurrence of sex chromosome abnormalities.

Among the 10,412 newborns studied there were 3 cases with trisomy-18 $(0.03 \%)$ and 1 case with trisomy-13 (0.01\%). Taylor (1968) reviewing the literature concerning a total of about 115,000 newborns reported an incidence of $0.02 \%$ for trisomy-18 and of $0.01 \%$ for trisomy-13. Our findings cannot be considered to differ significantly.

In the cases with Down's syndrome the most important single factor different from the normals was the advanced maternal age, a fact well established by all authors who studied this condition.

Pleydell in 1957 reported data suggesting a clustering of cases of Down's syndrome in space and time. Similar findings were reported later by Stoller and Collmann (1966). As Leck (1966) points out none of the above-mentioned reports is entirely conclusive: the data did not prove with certainty that the clustering in space and time exceeded that which might be expected by chance.

In the present investigation the births of babies with Down's syndrome were evenly distributed in the two-year period of the survey, as was also found by Leck (1966) and Robinson and Puck (1967).

The incidence of Down's syndrome in the present survey is $0.21 \%$, higher than the incidence of $0.15 \%$ reported by Penrose (1963), of $0.16 \%$ by Leck (1966), of $0.11 \%$ by Robinson and Puck (1967), and of others. In our attempt to explain this higher incidence we have analysed different factors in the maternal and paternal health history, such as important infectious diseases before or at the beginning of pregnancy, $x$-ray exposure etc. From this analysis the only difference that we have been able to detect in the parental history of the cases with mongolism was a higher incidence of infectious hepatitis in the history of the mothers, 3 times higher than in the normal female population of a comparable age (aged 30 years and more). Though the number of cases with Down's syndrome was small, the difference was statistically significant.

Stoller and Collmann (1966) found an apparent relation between infectious hepatitis and Down's syndrome, but others (Stark and Mantel, 1966; Leck, 1966; and Ceccarelli and Torbidoni, 1967) have not confirmed these findings.

Unlike these other studies we have not tried to relate infectious hepatitis at the beginning of pregnancy with the birth 9 months later of a child with Down's syndrome, but we found that mothers 
who have had clinical infectious hepatitis before their pregnancy have a 3 times higher risk of having a child with Down's syndrome than mothers of a comparable age without a history of infectious hepatitis.

We believe that the problem of a possible relation between viral infections and birth of children with chromosomal abnormalities such as trisomy-21 cannot yet be considered as solved, and more extensive studies are needed.

If, however, a positive relation of infectious hepatitis and birth of cases with Down's syndrome does exist, as our study tends to show, then the higher incidence of Down's syndrome of the present study could perhaps be due to differences in the incidence of infectious hepatitis between the ethnic groups studied.

Part of this investigation was supported by PHS Research Grant No. 5R01 NBO 6390 01-03 from the United States National Institute of Neurological Diseases and Blindness, and by Research Grant No. 423/608/764 from the Royal Hellenic Research Foundation.

\section{REFERENCES}

Bergemann, E. (1961). Geschlechtschromatinbestimmungen am Neugeborenen. Schweizerische medizinische Wochenschrift, 91, 292.

Carr, D. H. (1965). Chromosome studies in spontaneous abortions. Obsterics and Gynecology, 26, 308.

Ceccarelli, G., and Torbidoni, L. (1967). Viral hepatitis and Down's syndrome. Lancet, 1, 438.

Court Brown, W. M. (1968). Males with an XYY sex chromosome complement. Fournal of Medical Genetics, 5, 341.

de Grouchy, J., Roubin, M., and Passage, E. (1964) Microtechnique pour l'étude des chromosomes humains à partir d'une culture de leucocytes sanguins. Annales de Génétique, 7, 45

Frasier, S. D., Crudo, F. S., Jr., and Farrell, F. J., Jr. (1964). Buccal smears in the newborn female. Fournal of Pediatrics, 65,222

Frøland, A. (1967). Seasonal dependence in birth of patients with Klinefelter's syndrome. Lancet, 2, 771 .

Klinger, H. P. (1957). The sex chromatin in fetal and maternal portions of the human placenta. Acta Anatomica, 30, 371.

Kohn, G., Winter, J. S. D., and Mellman, W. J. (1968). Trisomy $\mathrm{X}$ in three children. Fournal of Pediatrics, 72, 248.
Leck. I. (1966). Incidence and epidemicity of Down's syndroffie. Lancet, 2, 457.

Maclean, N., Harnden, D. G., and Court Brown, W. M. (196). Abnormalities of sex chromosome constitution in newbōn babies. Lancet, 2, 406.

$\longrightarrow,-\longrightarrow$, Bond, J., and Mantle, D. J. (1964). Sex-chrom $\stackrel{\vec{m} \text { - }}{-}$ árquez-Monter, H., Carnevale-López, A., and Kofman-Alfaroos. (1968). Sex chromatin survey in 3000 newborn infants in Mexico. Pediatrics, 41, 664.

Moore, K. L. (1959). Sex reversal in the newborn babies. Lan 1,217

- -, and Barr, M. L. (1955). Smears from the oral mucosa in the detection of chromosomal sex. ibid., 2, 57 .

Moorhead, P. S., Nowell, P. C., Mellman, W. J., Battips, D. \& and Hungerford, D. A. (1960). Chromosome preparations of leucocytes cultured from human peripheral blood. Experimental Cell Research, 20, 613.

Naik, S. N., and Shah, P. N. (1962). Sex chromosome abnormginties in newborn babies in India Science, 136, 1116.

Pantelakis, S. N., and Panagopoulos, G. (1968). Sex chromatirîn human amnion membranes (Greek). Iatriki Athinai, \$3, 479.

Penrose, L. S. (1963). The Biology of Mental Defect. 3rd $\stackrel{\overrightarrow{\biguplus d}}{.}$ Sidgwick and Jackson, London.

Pleydell, M. J. (1957). Mongolism and other congenital abresmalities. An epidemiological study in Northamptonshife. Lancet, 1, 1314.

Robinson, A., and Puck, T. T. (1965). Sex chromatin in newboros: presumptive evidence for external factors in human nēndisjunction. Science, 148, 83.

- and - (1967). Studies on chromosomal nondisjunction in man. II. American fournai of Human Genetics, 19, $112 \mathrm{D}$

Smith, D. W., Marden, P. M., McDonald, M. J., and Speckhard, 시. (1962). Lower incidence of sex chromatin in buccal smegrs of newborn females. Pediatrics, 30, 707.

Stark, C. R., and Mantel, N. (1966). Viral hepatitis and Down's sundrome. Lancet, 2, 859.

Stoller, A., and Collmann, R. D. (1966). Viral hepatitis and DQwnds syndrome. ibid., 2, 339.

Szulman, A. E. (1965). Chromosomal aberrations in spontarapers human abortions. New England fournal of Medicine, 272801.

Taylor, A. I. (1963). Sex chromatin in the newborn. I ancets 912.

- (1968). Autosomal trisomy syndromes: A detailed study 27 cases of Edward's syndrome and 27 cases of Patau's syndrome. fournal of Medical Genetics, 5, 227.

- , and Moores, E. C. (1967). A sex chromatin survey $\frac{0}{9}$ newborn children in two London Hospitals. ibid., 4, 258.

W'iesli, B. (1962). Vergleich des phäno typischen und zellkeynmorphologischen Geschlectes bei 3029 Neugeborenen. Anatomica, 51, 377.

Correspondence to S. N. Pantelakis. Institute Child Health, Goudi, Athens 608, Greece. 